\section{5th International Conference}

\section{MODERN TRENDS IN TRAFFIC, LOGISTICS AND ECOLOGY FOR SUSTAINABLE DEVELOPMENT}

\section{Vlašić (Travnik, Bosnia and Herzegovina) - 2014}

Organized by the International University of Travnik and the Faculty of Traffic and Transport Sciences, University of Zagreb, the $5^{\text {th }}$ International Conference "Modern Trends in Traffic, Logistics and Ecology for Sustainable Development" was held on 23 and 24 May at Vlašić. The basic aim of the Conference was to consider the modern trends in traffic, logistics and ecology as function of sustainable development. At the Conference several topics were covered with the emphasis on sustainable development of economy and the society as a whole. This year's International Conference was opened by the Rector of the International University of Travnik, Prof. Ibrahim Jusufranić, Ph.D. On behalf of the Faculty of Traffic and Transport Sciences, the co-organizer of the Conference, the audience was addressed by Prof. Sadko Mandžuka, Ph.D. On behalf of the Government of the Central Bosnia Canton the Conference participants were addressed by: the Prime Minister, Mr. Tahir Lendo, as well as the ministers from the Government: Mr. Sedžad Milanović, Minister of Agriculture and Mr. Jozo Lučić, Minister of the Interior. On behalf of the district of Travnik the participants were greeted by Mr. Semin Konjalić, Deputy Head.

The most important topics were: Traffic (Traffic policy, Science and education in traffic, Traffic safety, Intelligent Transportation systems, Management in traffic, etc.), Logistics (Transport logistics, Logistic and distributive centres, Warehousing and inventory management, Logistics and forwarding), and Ecology (Global ecological issues, Ecology in traffic, Manage- ment in ecology, Urban ecology, etc.). The Conference was attended by a number of scientists, experts and distinguished professors from the field, coming from Bosnia and Herzegovina, Croatia, England, Serbia and Montenegro. There were also the representatives of the Government of Central Bosnia Canton and the Municipality of Travnik.

Various approaches to solving problems in traffic, logistics, and ecology at all levels of decision-making need to enable raising of the operative efficiency and improvement of the process in creating the quality of the traffic, logistic, and ecological services themselves. The end objective is oriented to accelerated economic growth and development with faster and more efficient overcoming of the existing unfavourable trends, both in Bosnia and Herzegovina, and in the region as well. All this needs to be considered within the process of globalization which brings along a number of unknowns and dilemmas for the global development. The scientific and professional papers are expected to contribute to raising to a higher level the scientific and technical competencies of all those involved or those who will have the need to deal with traffic, logistics, ecology and their impacts on business effects of individual companies and the economy as a whole.

At the end of the Conference respective conclusions and recommendations have been adopted, and the most significant are the following:

a) To define the vision, mission, and strategy of implementing new framework traffic policy and traffic development of Bosnia and Herzegovina, combining the policies of entities, that will define and orient the future traffic development in Bosnia and Herzegovina for the period until 2030 .

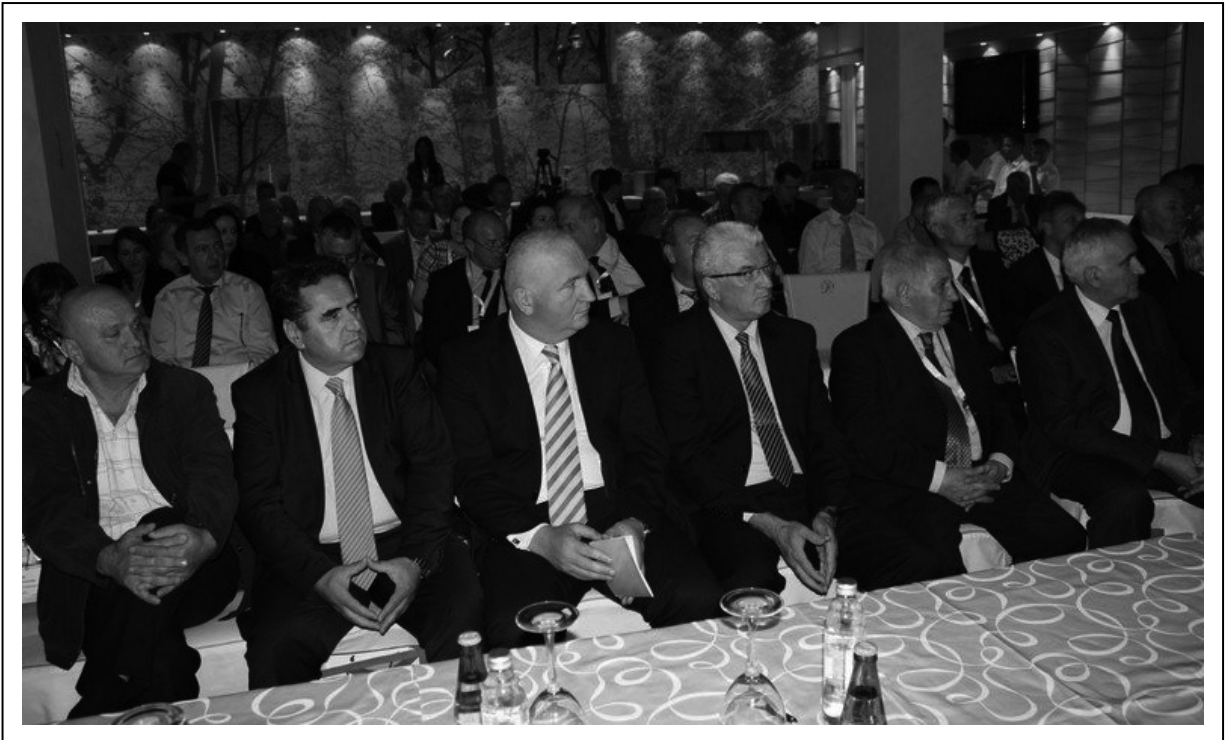

The opening ceremony of the Conference "Modern Trends in Traffic, Logistics and Ecology for Sustainable Development" 
b) To determine and adopt the strategy of road traffic safety to realize the objective of $50 \%$ reduction of the number of fatalities by 2020 .

c) To maximally stimulate the cooperation with the European Union, as well as regional cooperation.

d) As part of past implementation of measures to improve the road traffic safety and environmental protection the current measures have given certain results. However, the continuation of the trend of improving road traffic safety requires their re-analysis, expansion and stricter direct implementation. Here, special attention should be directed to im- provement of the protection of passengers in the car, and implementation of new technological solutions, such as intelligent transportation systems (ITS).

During the Conference special emphasis was on the need to introduce new technologies for the improvement of road safety, such as driver's assistance systems, eCall, cooperative systems for intelligent road safety, etc.

Sadko Mandžuka, Ph.D.

Faculty of Transport and Traffic Sciences University of Zagreb 